\title{
"The system of the key indicators of formation of attractive investment climate of Ukraine and peculiarities of their management"
}

\begin{tabular}{|c|c|}
\hline AUTHORS & $\begin{array}{l}\text { Liudmyla Gavatiuk (D https://orcid.org/0000-0002-5538-3884 } \\
\mathbb{R} \text { http://www.researcherid.com/rid/S-1874-2016 } \\
\text { Alina Korbutiak (D https://orcid.org/0000-0002-9330-7145 } \\
\mathbb{R} \text { http://www.researcherid.com/rid/S-4327-2016 } \\
\text { Nataliya Sokrovolska (D https://orcid.org/0000-0001-8778-7317 } \\
\mathbb{R} \text { http://www.researcherid.com/rid/R-8418-2016 } \\
\text { Maksym Karvatskyi (D https://orcid.org/0000-0002-6675-7650 } \\
\mathbb{R} \text { http://www.researcherid.com/rid/S-4690-2016 } \\
\text { Eduard Yurii } \mathbb{D} \text { http://orcid.org/0000-0001-9987-4629 } \\
\mathbb{R} \text { http://www.researcherid.com/rid/R-9472-2016 }\end{array}$ \\
\hline ARTICLE INFO & $\begin{array}{l}\text { Liudmyla Gavatiuk, Alina Korbutiak, Nataliya Sokrovolska, Maksym Karvatskyi } \\
\text { and Eduard Yurii (2020). The system of the key indicators of formation of } \\
\text { attractive investment climate of Ukraine and peculiarities of their management. } \\
\text { Problems and Perspectives in Management, 18(1), 154-170. } \\
\text { doi:10.21511/ppm.18(1).2020.14 }\end{array}$ \\
\hline DOI & http://dx.doi.org/10.21511/ppm.18(1).2020.14 \\
\hline RELEASED ON & Thursday, 27 February 2020 \\
\hline RECEIVED ON & Saturday, 14 December 2019 \\
\hline ACCEPTED ON & Monday, 10 February 2020 \\
\hline LICENSE & $\begin{array}{l}(c)) \mathrm{EY} \\
\text { This work is licensed under a Creative Commons Attribution } 4.0 \text { International } \\
\text { License }\end{array}$ \\
\hline JOURNAL & "Problems and Perspectives in Management" \\
\hline ISSN PRINT & $1727-7051$ \\
\hline ISSN ONLINE & $1810-5467$ \\
\hline PUBLISHER & LLC "Consulting Publishing Company "Business Perspectives" \\
\hline FOUNDER & LLC "Consulting Publishing Company "Business Perspectives" \\
\hline
\end{tabular}

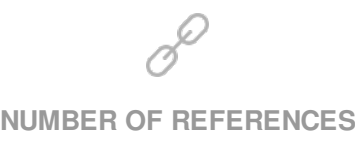

41

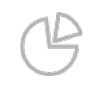

NUMBER OF FIGURES

7

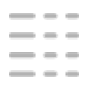

NUMBER OF TABLES

3

(C) The author(s) 2022. This publication is an open access article. 


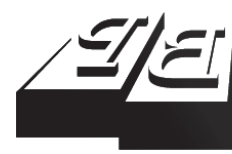

\section{BUSINESS PERSPECTIVES}

9

LLC "CPC "Business Perspectives" Hryhorii Skovoroda lane, 10, Sumy, 40022, Ukraine www.businessperspectives.org

Received on: $14^{\text {th }}$ of December, 2019 Accepted on: $10^{\text {th }}$ of February, 2020 Published on: $27^{\text {th }}$ of February, 2020

(C) Liudmyla Gavatiuk, Alina Korbutiak, Natalia Sokrovolska, Maksym Karvatskyi, Eduard Yurii, 2020

Liudmyla Gavatiuk, Ph.D. in Economics, Assistant, Department of Public, Corporate Finance and Financial Management, Yuriy Fedkovych Chernivtsi National University, Ukraine. (Corresponding author)

Alina Korbutiak, Ph.D. in Economics, Associate Professor, Department of Public, Corporate Finance and Financial Management, Yuriy Fedkovych Chernivtsi National University, Ukraine.

Natalia Sokrovolska, Ph.D. in Economics, Associate Professor Department of Public, Corporate Finance and Financial Management, Yuriy Fedkovych Chernivtsi National University, Ukraine.

Maksym Karvatskyi, Ph.D. in Economics, Associate Professor, Department of Public, Corporate Finance and Financial Management, Yuriy Fedkovych Chernivtsi National University, Ukraine.

Eduard Yurii, Ph.D. in Economics, Associate Professor, Department of Public, Corporate Finance and Financial Management, Yuriy Fedkovych Chernivtsi National University, Ukraine.

This is an Open Access article, distributed under the terms of the Creative Commons Attribution 4.0 International license, which permits unrestricted re-use, distribution, and reproduction in any medium, provided the original work is properly cited.

Conflict of interest statement: Author(s) reported no conflict of interest

Liudmyla Gavatiuk (Ukraine), Alina Korbutiak (Ukraine), Natalia Sokrovolska (Ukraine), Maksym Karvatskyi (Ukraine), Eduard Yurii (Ukraine)

\title{
THE SYSTEM OF THE KEY
}

INDICATORS OF FORMATION

OF ATTRACTIVE INVESTMENT

CLIMATE OF UKRAINE

AND PECULIARITIES

OF THEIR MANAGEMENT

\begin{abstract}
Ukraine, as a young country, is creating the investment market, which is the most important component of the national economy under the challenges and threats of the XXI century, instability and hybrid war. The study aims to analyze the investment climate and investment attractiveness of Ukraine and to identify key indicators through the political, legal, economic, social, and other conditions under which its investment market will become attractive. The dynamics investigation of foreign direct investments (FDI) inflows into Ukraine during 2002-2018, their structural analysis enabled to identify the periods of the most significant fluctuations and to state the reasons for such changes, to differentiate priority sectors of the Ukrainian economy being of financial interest to foreign investors, which is as a whole the basis of the attractive investment climate formation and management in the country.
\end{abstract}

The methods of financial management system, including the method of SWOT analysis, were applied to determine investment weaknesses, threats, strengths and opportunities, considering the peculiarities of their management.

As a consequence of the analysis on the reasons for the reduction of foreign investments in the country economy, it is proved that the proposed mechanism for improving the investment climate in the country will allow increasing FDI inflows and financing the general capital investments.

\section{Keywords}

JEL Classification

\section{INTRODUCTION}

The economic growth of the countries is largely ensured by the level of scientific, technical and innovative activity development in all spheres of economy. The share of new or improved technologies, products and equipment in developed countries comprise from 70 to $85 \%$ of the gross domestic product growth. Opportunities for development, implementation, and use of new and improved technologies, products depend on the state of the investment climate in the country, the investments volume and structure.

Improving the investment climate in the country and intensifying the investment activity have become a particularly sound problem in the country today.

At the present stage, the most important among the existing destructive tendencies is the problem of the investment resources lack in the 
economy of Ukraine and the lack of conditions for creating an attractive investment climate. High investment attractiveness is a key factor in improving the competitiveness of the country, ensuring high and sustainable economic growth, which is why one of the key tasks facing the Ukrainian authorities now is to increase the investment attractiveness of the state economy. Today, Ukraine, as never before, needs investment for the economic development. The most demanded form of investment for the country's economy is foreign direct investment, as they allow implementing the large and important projects; besides, the country gets the latest technologies, new corporate governance practices and more. Some steps have been taken in Ukraine to improve the investment climate. However, in general, it remains unfavorable. Low investment attractiveness of Ukraine hinders the modernization of its economy, the implementation of urgent reforms, the emergence of a deep systemic crisis, and overcoming economic destructions.

That is why it is necessary to arrange the system of key indicators that influence investment decisionmaking and management of strengths and opportunities for investment development of Ukraine.

\section{LITERATURE REVIEW}

As the institutionalization of investment processes in accordance with world standards is being transformed in Ukraine, it is important to consider and summarize foreign experience in the direction of forming an attractive investment climate.

The main principles and problems of investment process management at the international level are investigated by Aschauer (1989), where the basic phenomena of international investment processes were examined.

The results of the European Union investment strategy revitalization by developing the appropriate models to analyze the implications of each of the functional changes in the investment strategies of the European countries were highlighted in details by Major and Szilagyi (2009). The authors of this study analyze the changes in the country's investment climate and determine the complexity of large public investment projects in an open economy.

The country's competitiveness and level of economic development depend not only on the investment climate but also on the focus area of directing the investment flows through the introduction of fiscal instruments to create favorable conditions for investment in certain sectors of the economy. The role of government in the economic development of the country and the existing problems were analyzed in the work of Sineviciene and Vasiliauskaite (2011).
Government subsidies adversely affect the investment behavior of $R \& D$ enterprises. To demonstrate the investment behavior of enterprises under the influence of government subsidies, Yu, Gio, Le-Nguyen, Barnes, and Zhang (2016) presented a regression model that demonstrates the reaction of $\mathrm{R} \& \mathrm{D}$ undertakings in case of an increase in government subsidies.

Investment activity is an important aspect of state development since most economical and social issues cannot be solved without the development of investment activity. Investments are the most important means of increasing the scientific and technological progress, improving the quality indicators the country's of economic activity, as well as improving the attractiveness of the country's investment climate, which is one of the effective methods of socio-economic transformation. The main problems of the favorable investment climate formation were argued in the work of Alexander and Eberley (2018).

One of the main priorities of economic development of any country is the revitalization of investment processes since there is no possible economic growth and efficient functioning of the economy of any state without them. It is almost impossible to satisfy the investment needs of the state only at the expense of internal investment resources, so naturally every country in the world faces the problem of attracting foreign investment resources. Rognlie, Shleifer, and Simsek (2018) argue that in order to ensure the efficient functioning of the country's economy and its economic growth, it is 
necessary to have a positive investment image and to constantly work on improving the country's position in investment rankings, which play an important role in shaping an attractive investment climate.

The need to intensify investment processes is highlighted in the work of Vertiakova and Plotnikov (2017) by analyzing the patterns of sustainable development of the world countries, emphasizing the importance of meeting the requirements of the world community regarding economic, investment, environmental, social, and other issues, and also analyzes the global trends of investment development and determines the importance of taking them into account in the development of domestic investment policy and offers recommendations for their improvement.

At the same time, it should be noted that different instruments of investments stimulation were applied in Ukraine, starting from granting the preferential regime for foreign investments (Law of Ukraine "On the regime of foreign investment" (Legislation of Ukraine, 1996)), creation of special economic zones, use of fiscal instruments and so on. However, considering the large number of priority areas and the state instruments dispersion behind them, the constant changes in the institutional environment did not allow forming a transparent state investment policy in the country and providing a favorable investment climate.

Various aspects of the country's investment attractiveness have been highlighted in recent years. Thus, Rzaev and Vakulova (2016) outlined the methods for assessing the investment attractiveness at the country level and prospects for their use in economic analysis. Blakyta, Guliaieva, Vavdijchyk, Matusova, and Kasianova (2018) proposed an integral indicator for assessing the security of the investment environment and identified a list of Ukraine's investment environment security factors; assessed Ukraine's security investment environment and that its of Western neighbors, i.e., member states of the European Union.

Maslak and Talover (2016) comprehensively assessed the investment attractiveness of the country. Grytsaienko (2017) analyzed the investment attractiveness of Ukraine compared to the coun- tries of the former USSR republics. Paranchuk and Korbutyak (2013) distinguished the factors influencing the investment attractiveness of the national economy and proposed the criteria for its evaluation.

Despite the large number of published articles and scientific papers, such concepts as investment, favorable investment and investment climate formation and management system still need a deep and constant consideration, especially in the face of the fast-changing economic environment.

\section{RESEARCH PURPOSE}

The main aim of the study is to evaluate the investment climate and investment attractiveness of Ukraine and to identify key indicators of investment decision-making and determine the quality of the environment in which investment entities operate, that will help identify key areas of governance policy.

\section{RESEARCH METHODS}

In the course of the study, the following methods were used: system analysis and SWOT-analysis to study key factors of formation investment climate, as well as to identify opportunities and strengths for investment development; structural and coefficient analysis - to identify key areas of investment, to construct the mechanism for managing the country's investment climate, and to form recommendations for enhancing the country's investment attractiveness in general.

The positive and negative factors of the investment climate are evaluated by international rankings and indices. An important information resource, in this case, is the study of international ranking agencies that highlight the key indicators of the industry, region and country investment climate.

Moody's Investors Service, Standard \& Poor's Rating Services, Fitch Ratings, Heritage Foundation/Wall Street Journal, Transparency International, Euromoney, Economic Intelligence Union and others are among the various international methods of assessing investment attractive- 
ness. This research aims to assess the political, economic, and social situation of the country, which is especially relevant for the Ukrainian economy.

The Global Competitiveness Index is important, which assesses the ability of a country's economy to achieve high business performance and, based on this, high rates of economic growth and prosperity. The index is a comparison of 12 countries in the world. These are institutions, infrastructure, macroeconomic stability, health care, primary education, higher education and vocational training, product market efficiency, labor market, financial market development level, technological readiness, market size, business development level, innovation. The index is calculated taking into account the concept of comparing the countries' competitiveness at different stages of the economic development. It is being developed by the World Economic Forum (WEF). Ukraine takes 81st place out of 137 countries in the ranking of world countries by the Global Competitiveness Index 2017-2018.

The Ease of Doing Business index assesses the business climate of countries by the simplicity of the administrative procedures, most importantly for small and medium-sized businesses, by two types of indicators. This is an indicator of the strength of the legal institutions that regulate the business. These are indicators that reflect the complexity and cost of regulatory procedures, namely enterprises registration, obtaining permits for construction, connection to the energy supply system, obtaining a loan, registration of property, taxation, closure of the enterprise, international trade. The index is calculated by the World Bank and is called Doing Business 2019. In 2018, Ukraine ranks 71st out of 190 countries evaluated in this index.

One of the most famous international investment climate indicators is the International Business Compass Index, which since 2012 is calculated by $\mathrm{BDO}$ in cooperation with the Hamburg Institute of the World Economy (BDO, 2019). BDO Business Compass assesses the country's investment attractiveness by presenting the information in three dimensions: economic factors, the political-legal field, and socio-cultural conditions. On the one hand, the country's attractiveness for potential investment decisions is at the forefront, which clearly reflects the economic outlook. On the other hand, economic factors can only partially reflect the situation in the country as political, legal, social and cultural aspects also play a role and ultimately affect the country ranking. These three dimensions are correlated with each other and are statistically completely independent. From a statistical point of view, the attractiveness of a country is variable due to the interaction of several factors. Selected indicators can have both a positive and a negative effect on a country's ranking, and thus increase or decrease the country's investment attractiveness. In the ranking of countries' investment attractiveness of the International Business Compass for 2016, Ukraine's place decreased by 41 positions compared to the previous period and Ukraine occupied $130^{\text {td }}$ place (in $2015-89^{\text {th }}$ place). Aggravation occurred in all categories. Particularly significant is the fall in terms of economic indicators. First of all, similar results are caused by the political crisis and events in the Eastern part of the country. BDO analysts commented on the downgrade: "Not surprisingly, Ukraine represents the biggest loser in this year's ranking. This country has dropped 41 places compared to last year, due to worsening in all categories. This is primarily a result of the political crisis and continuing civil war in the Eastern part of the country. For the economic indicators, the drop is observed to be particularly significant". However, already in 2018 in the ranking of the countries of the International Business Compass investment attractiveness, Ukraine has increased by 3 positions compared to the previous period and Ukraine took $131^{\text {st }}$ place (in $2017-134^{\text {th }}$ place).

The Global Innovation Index 2018 assesses the investment climate because investment in innovation is a prerequisite for increasing the longterm economic growth. In 2018, in the Global Innovation Index, Ukraine improved its position by 8 steps and was ranked $52^{\text {nd }}$. In 2017, it was ranked 50th (WIPO, 2019). Costs for innovation and research, productivity, efficiency, research competition, researchers and high-tech companies, patent registration were evaluated.

\section{RESULTS}

The investment climate is a set of political, legal, economic, financial, cultural, natural, and other indicators that determine the degree of the in- 
vestment activity attractiveness, its profitability, the level of risks, determine the motivation of investors to equity contribution. It is related to the level of economic development, its problems and destructions. Destruction is a brake on economic development, one of the main drivers of the unfavorable investment climate. Destruction takes place in the economy. This is an "infraction of structure of the economic and industrial ties that have developed, a schedule, the collapse of the economy" or "ruin, decline, devastation, destruction, demolition” (Grytsaienko, 2014).

The authors state that destruction in the economy is the devastation or deformation of its structure, financial system, monetary circulation, public finances, economic and industrial relations, loss of important functions, acquisition of signs that impede the development, lead to degradation, deindustrialization, collapse of the official sector and the development of the shadow sector, the decline of the social sphere, the galloping inflation, devaluation, corruption, abrupt decline in living standards. Much of the economic devastation arose in Ukraine in the 1990s, in an era of transition from a command centralized, planned economy to market economy. The country has experienced the so-called "transformational downturn." In 1999, Ukraine GDP made up only 40.8\% of GDP in 1990.

Much of the economic devastation arose in Ukraine after the transformational recession. There was formed a vulnerable state of foreign markets, and prices deformed the industrial structure of the raw materials economy. In the country's GDP, the share of industry, especially processing, has sharply decreased. The shadow economy, shadow incomes, and corresponding employment expanded. For many years, public finances, including the state budget, state corporations, the Pension Fund of Ukraine have been experiencing the deficits (Ishchuk, 2018).

There is a systemic dependence of Ukraine on loans from the IMF and other international organizations. There was an uncontrolled depreciation of the national currency. International reserves are lost. There is the collapse of people living standards, real incomes, savings, purchasing power, and rising prices. Emigration flows of an economic nature and internal displacement caused by the war became massive. The prices for housing and communal services and tariffs for heat, hot and cold water, and other services increased in disproportion to the incomes of citizens, their purchasing power. The dominant part of the population was transferred to subsidies. Large economic, military, and strategic losses were incurred as a result of annexation of Crimea, occupation of part of the territory of Donetsk and Luhansk regions, and hybrid war. The major part of the Navy, strategic industrial enterprises, have been lost, and imbalances in the production and consumption of industrial products, including coal, have arisen. A systemic banking crisis has developed. There were liquidated 100 banks in a short time. From the beginning of 2014 to the end of 2018, almost 116,000 people were released from the banking system, and nine more were subsequently liquidated. More than half of the banking system assets are nationalized and transferred to state ownership. The country has acquired a risky status with negative investment image and "destructive economy" (Ministry of Finance of Ukraine).

The modernization of a destructive economy is possible only by creating the conditions for large volumes of domestic and foreign investments, termination of capital flight, implementation of fundamental national investment programs and projects. An important factor of favorable investment attractiveness for the economy of Ukraine is the nature of regulatory influence, registration requirements for domestic and foreign investors, the state of licensing of financial institutions, certification, standardization, as well as control by public authorities, the existence of corruption schemes, bribery, shadow mechanisms, and the national legislation degree to the international acts requirements.

For the investment market development, its attractiveness, and the improvement of the investment climate, it is important to create the conditions for attracting foreign investments, first of all, direct investments. Foreign direct investment is a longterm investment. They are carried out by non-resident companies in the economy of another country, in particular, Ukraine, for setting up and building the enterprises, other objects, authorized and share capital acquisition. To attract foreign direct investment, Ukraine offers major investment pro- 
jects, including an agricultural complex with the fish specialization, a complex for the grain processing and storage, livestock complexes, technological lines for continuous casting of steel in the metallurgical industry, and many others.

Foreign direct investment in Ukraine's economy over the past 17 years has been fairly unsteady. The dynamics of their receipt for the period 2002-2018 are shown in Table 1.

Table 1. Foreign direct investment in Ukraine*

Source: Created by the authors according to the data from State Statistics Service of Ukraine (2019).

\begin{tabular}{|c|c|c|c|c|}
\hline \multirow[b]{2}{*}{ Year } & \multirow[b]{2}{*}{$\begin{array}{c}\text { Foreign } \\
\text { direct } \\
\text { investment, } \\
\text { USD million }\end{array}$} & \multicolumn{3}{|c|}{ Dynamics (up to the previous year) } \\
\hline & & $\begin{array}{l}\text { Absolute } \\
\text { growth } \\
\text { (decrease), } \\
\text { USD million }\end{array}$ & $\begin{array}{c}\text { Dynamics } \\
\text { index, } \\
\%\end{array}$ & $\begin{array}{c}\text { Growth rate } \\
\text { (reduction), } \\
\%\end{array}$ \\
\hline
\end{tabular}

\begin{tabular}{c|c|c|c|c}
\hline 2002 & 693 & $\ldots$ & $\ldots$ & $\ldots$ \\
\hline 2003 & 1,424 & 731 & 205.5 & 105.5 \\
\hline 2004 & 1,715 & 291 & 120.4 & 20.4 \\
\hline 2005 & 7,808 & 6,093 & 455.5 & 355.5 \\
\hline 2006 & 5,604 & $-2,204$ & 71.8 & -28.2 \\
\hline 2007 & 9,891 & 4,287 & 176.5 & 76.5 \\
\hline 2008 & 10,913 & 1,022 & 110.3 & 10.3 \\
\hline 2009 & 4,816 & $-6,097$ & 44.1 & -55.9 \\
\hline 2010 & 6,495 & 1,679 & 134.9 & 34.9 \\
\hline 2011 & 7,207 & 712 & 111.0 & 11.0 \\
\hline 2012 & 8,401 & 1,194 & 116.6 & 16.6 \\
\hline 2013 & 4,499 & $-3,902$ & 53.6 & -46.4 \\
\hline 2014 & 410 & $-4,089$ & 9.1 & -90.9 \\
\hdashline 2015 & 2,961 & 2,551 & 722.2 & 622.2 \\
\hline 2016 & 3,130 & 169 & 105.7 & 5.7 \\
\hline 2017 & 2,202 & -928 & 70.4 & -29.6 \\
\hdashline 2018 & 2,355 & 153 & 106.9 & 6.9 \\
\hline
\end{tabular}

Note: *Data for 2014-2018 are given without taking into account the temporarily occupied territories of the Autonomous Republic of Crimea and Sevastopol and without part of the temporarily occupied territories in Donetsk and Luhansk regions.

Table 1 data show that FDI inflows to Ukraine from 2002 to 2018 fluctuate significantly and depend considerably on the state and changing political and economic situation in the country and in the world. Thus, in 2005, hoping for positive changes after the events of 2004, foreign investors invested USD 7,808 million in the Ukrainian economy, which is 4.6 times more than in the previous year.

The largest amount of foreign investments in Ukraine occurred in 2008, i.e., USD 10,913 million, which was 6.4 times, or USD 9,198 million more than in 2004. The significant decrease in FDI inflows during 2009 is largely explained by the global economic crisis, so the inflow decreased by $55.9 \%$, compared to 2008, amounting to USD 6,097 million. In the next period, from 2010 to 2012, there is a gradual increase in foreign investments, when revenues in 2012 increased to USD 8,041 million. However, already in 2013, political instability in Ukraine led to a significant reduction in foreign investment, which amounted only to USD 410 million in 2014, which is only $9.1 \%$ of 2013 revenue.

Despite this, in 2018, a slight increase in revenue, totaling USD 153 million, or $6.9 \%$, continues to indicate a lack of confidence of foreign investors in the ability to do business sustainably and improve the country's investment climate (Foreign Direct Investment in Ukraine, State Statistics Service of Ukraine, 2019).

Table 2. The foreign direct investment structure in the Ukrainian economy by countries

\begin{tabular}{|c|c|c|c|}
\hline \multirow{3}{*}{ Countries } & \multicolumn{3}{|c|}{$\begin{array}{l}\text { Source: Created the authors according to the data } \\
\text { from the State Statistics Service of Ukraine (n.d.) }\end{array}$} \\
\hline & \multicolumn{3}{|c|}{$\begin{array}{l}\text { The foreign investments } \\
\text { structure on January 1, \% }\end{array}$} \\
\hline & 2013 & 2016 & 2019 \\
\hline Austria & 4.8 & 3.6 & 3.1 \\
\hline United Kingdom & 4.8 & 5.6 & 6.1 \\
\hline Italy & 0.8 & 0.7 & 0.8 \\
\hline Cyprus & 30.8 & 30.8 & 27.5 \\
\hline The Netherlands & 16.4 & 19.0 & 22.0 \\
\hline Germany & 8.7 & 5.2 & 5.2 \\
\hline Poland & 1.7 & 2.1 & 1.8 \\
\hline Russian Federation & 6.0 & 1.3 & 3.3 \\
\hline France & 2.9 & 4.0 & 2.0 \\
\hline Switzerland & 2.1 & 4.3 & 4.8 \\
\hline The USA & 2.0 & 2.2 & 1.5 \\
\hline Other & 19.0 & 21.2 & 21.9 \\
\hline Total & 100.0 & 100.0 & 100.0 \\
\hline
\end{tabular}

More than $70 \%$ of total investment comes from the EU countries and about $30 \%$ comes from other countries. Table 2 presents the list of countries that make the largest investments in the economy of Ukraine and the investments share of these countries in the total amount of foreign direct investment in Ukraine.

As one can see from Table 2, significant changes have occurred in the foreign direct investment structure in the economy of Ukraine from 2013 to 2019. First, it should be noted that the largest 
amount of investment comes from Cyprus investors, whose share remained stable from 30.8\% in 2016 compared to 2013, and decreased by 3.3 points at the beginning of 2019 , to $27 \%, 5 \%$.

The Netherlands is the second largest investor. The total foreign direct investment by this country in to Ukraine's economy has increased from $16.4 \%$ in 2013 to $19.0 \%$ in 2016 , reaching $22.0 \%$ in the beginning of 2019. According to the State Statistics Service of Ukraine (2019), as of January 1, 2019, the Netherlands has invested USD 7,061 million in the Ukrainian economy; Cyprus had given USD 8,880 million. It can also be noted that in the beginning of 2019, compared to previous years, in the foreign direct investment structure in the Ukrainian economy, the share of investments from the UK increased from $4.8 \%$ to $6.1 \%$, and Switzerland had from $2.1 \%$ to $4.8 \%$. At the same time, the share of investments from Germany decreased from 8.7\% to $5.2 \%$, France had from $4.0 \%$ to $2.0 \%$, the USA had from $2.2 \%$ to $1.5 \%$. The share of investments in Ukraine from the Russian Federation at the beginning of 2016 compared to 2013 decreased significantly, i.e., from $6.0 \%$ to $1.3 \%$, but at the beginning of 2019, it increased again and amounted to $3.3 \%$ of total foreign direct investment.

Graphically, the foreign direct investment structure in Ukraine's economy by countries at the beginning of 2019 is presented in Figure 1.
The foreign direct investment structure in Ukraine's economy by type of economic activity at the beginning of 2019 is graphically depicted in Figure 2.

Industries with the highest priority for foreign investors remain the investments share, which at the beginning of 2019 increased by 2.8 percent, compared to 2016 and amounted to $33.0 \%$, which is definitely a positive fact.

It is important to analyze the total capital investment dynamics and structure in a country, which is an investment by their acquisition or manufacture for their personal use of tangible and intangible assets.

The largest amount of capital investments is the personal funds of enterprises and organizations, whose share in the total volume of capital investments in 2018 increased, compared to previous years and amounted to $71.3 \%$. It is also worth noting such favorable changes as the increase in the share of capital investments at the expense of the state budget, which share in 2016 was $2.3 \%$ of the total, in 2017, it increased to $3.4 \%$, and in 2018, it was already $4.0 \%$. The share of capital investments at the expense of local budget funds in $2017 \mathrm{com}$ pared to 2016 increased to $9.3 \%$, but in 2018, it decreased slightly and amounted to $8.7 \%$ of the total amount of investments. This demonstrates the

Source: Built by the authors.

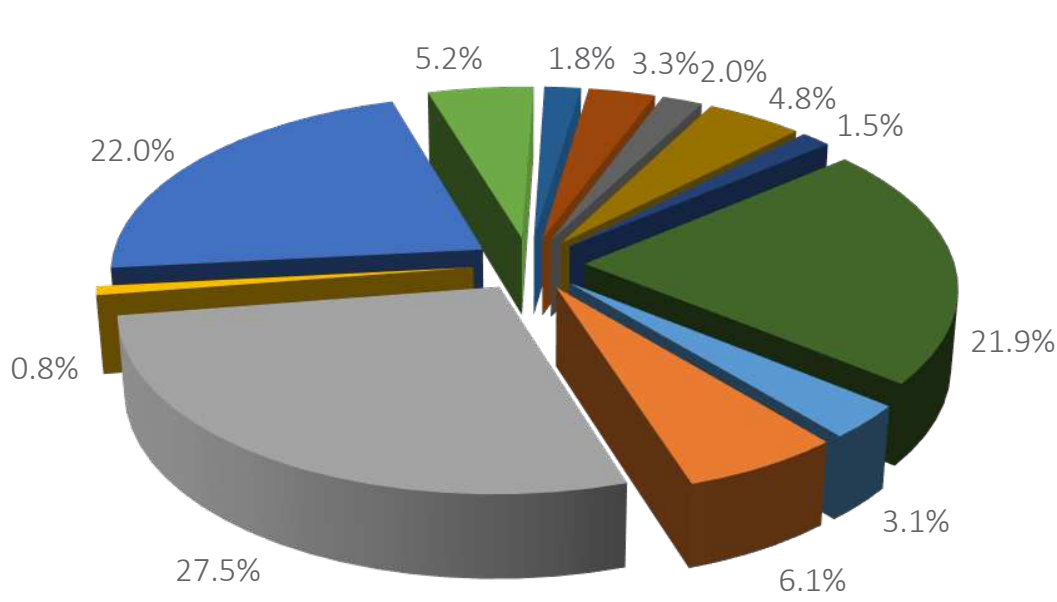

Figure 1. The foreign direct investment structure in Ukraine's economy by countries of the world as of January 1, 2019, \% 


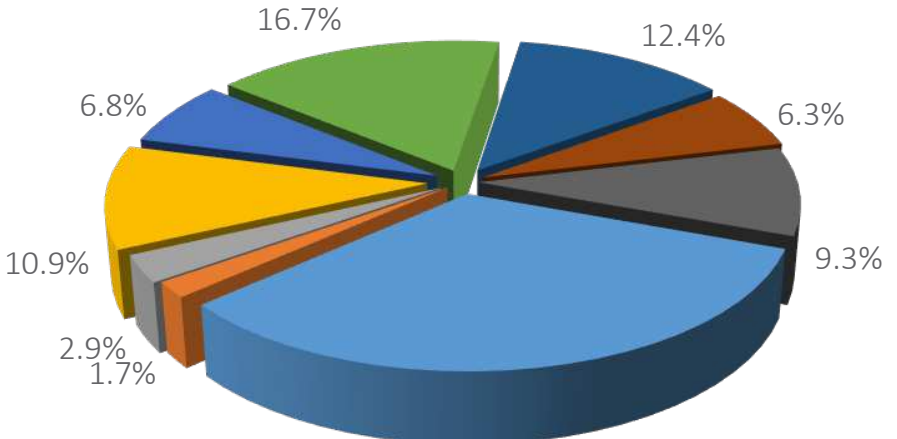

$33.0 \%$
- Industry

- Agriculture, forestry and fisheries

Construction

- Financial and insurance activities

Information and telecommunications

Wholesale and retailing

Real estate transactions

Professional, scientific and technical activities

Figure 2. The foreign direct investment structure in Ukraine's economy by type of economic activity as of January 1, 2019, \%

ability of local authorities to involve more in local and regional projects.

Really negative changes in the capital investments structure are significant reduction of investments at the expense of foreign investors: if in 2016, the funds of foreign investors accounted for $2.9 \%$ of total capital investments, then in 2018, count only $0.3 \%$ (State Statistics Service of Ukraine, 2019). This again confirms the conclusion that most foreign investors do not risk investing in the Ukrainian economy.
The structure of capital investments in Ukraine by the financing sources in 2018 is presented in Figure 3.

It is advisable to summarize the information given in Figure 6, which describes the system of key indicators of attractive investment climate formation and management.

To determine the indicators for shaping Ukraine's investment attractiveness, the SWOT analysis method will be applied, which will identify both

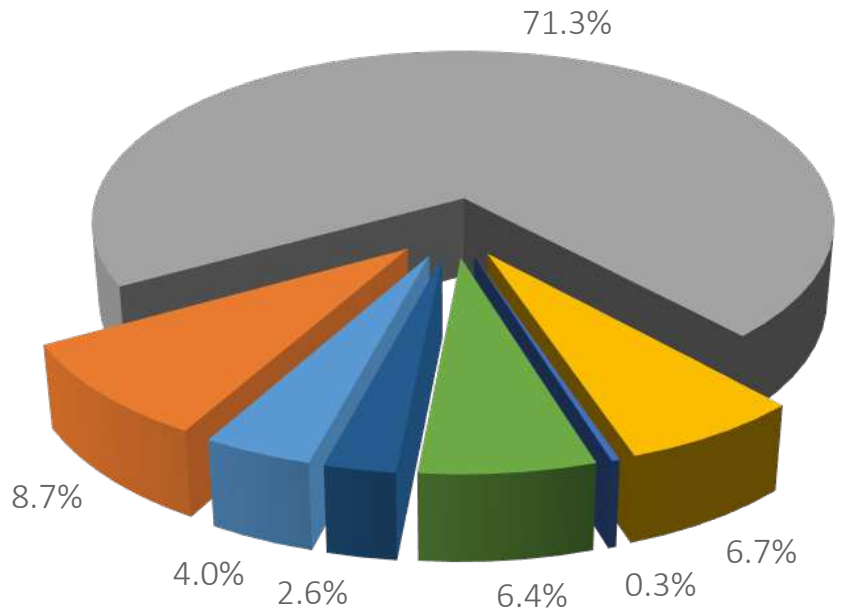

Figure 3. Structure of capital investments in Ukraine by the financing sources in $2018, \%$ 
Table 3. SWOT analysis results of factors and conditions of the investment attractiveness formation in Ukraine

Source: Created by the authors according to data of domestic enterprises.

\begin{tabular}{l|l}
\hline & $\vdots$ \\
Strengths & Weaknesses \\
\hline
\end{tabular}

Geographic location

Human capital

Ratification of the Association Agreement with the EU

Legislative changes and reforms

Availability of unique natural resources, minerals, and mineral

water

Education system

Internal market size

High potential of agribusiness, information technology, chemical

and energy industries (estimated by international experts)

Presence of competitive export-oriented enterprises
Large share of the shadow economy

Natural and migration reduction of the population

Government opacity and corruption

State budget deficit

Complexity and length of construction and tenure related

procedures

Institutional environment

Economic policy decisions driven by populist tendencies and the

desire to win votes

Macroeconomic instability

Low efficiency of financial and commodity markets

Low level of technological development

\section{Opportunities}

Improvement and compliance with legislation

Development of international relations

Transparency and fairness of justice

Property rights protection

Economic growth

Reducing the level of inflation and unemployment, the level of the shadow economy

Deregulation

Stabilization of public finances,

Improvement of the banking system,

Formation of a favorable business environment

\section{Threats}

Society corruption

Political instability

High inflation and unemployment

Population aging

Human development slowdowns and military aggression on East of

Ukraine threaten the national security

Raider capture

Deterioration of the economic situation

Difficult access to finance

Global changes of climate

World economic crises threats and benefits and opportunities for improving Ukraine's investment attractiveness (see Table 3).

Identifying the strengths and weaknesses that affect the country's investment attractiveness is an indicator of the need to take action to address deficiencies and create greater opportunities to increase the country's competitive advantage and investment attractiveness. And the use of existing opportunities allows realizing the existing innovative and human potential, and is a prerequisite for gradual strengthening of Ukraine's competitive position and adaptation of the national economy to global transformations.

Based on the SWOT analysis, the authors identify the relationship between the country's strengths and opportunities to improve the investment climate (see Figure 4), between the opportunities and weaknesses that affect the investment climate (see
Figure 5), and between threats and weaknesses that characterize the risk of the country's investment attractiveness deterioration (see Figure 6).

The expected improvement in the investment attractiveness and business climate of Ukraine, as well as international support for development projects, can be a comparative advantage of the country, given a number of strengths.

As a result of forming a SWAT matrix of the relationship between weaknesses and opportunities of improving the country's investment climate, the previous can compensate the first ones.

On the other hand, as a result of forming a SWAT matrix of relationship between threats and weaknesses of improving the investment activities, they are most likely to be affected by negative external factors (threats) (see Figure 6). 


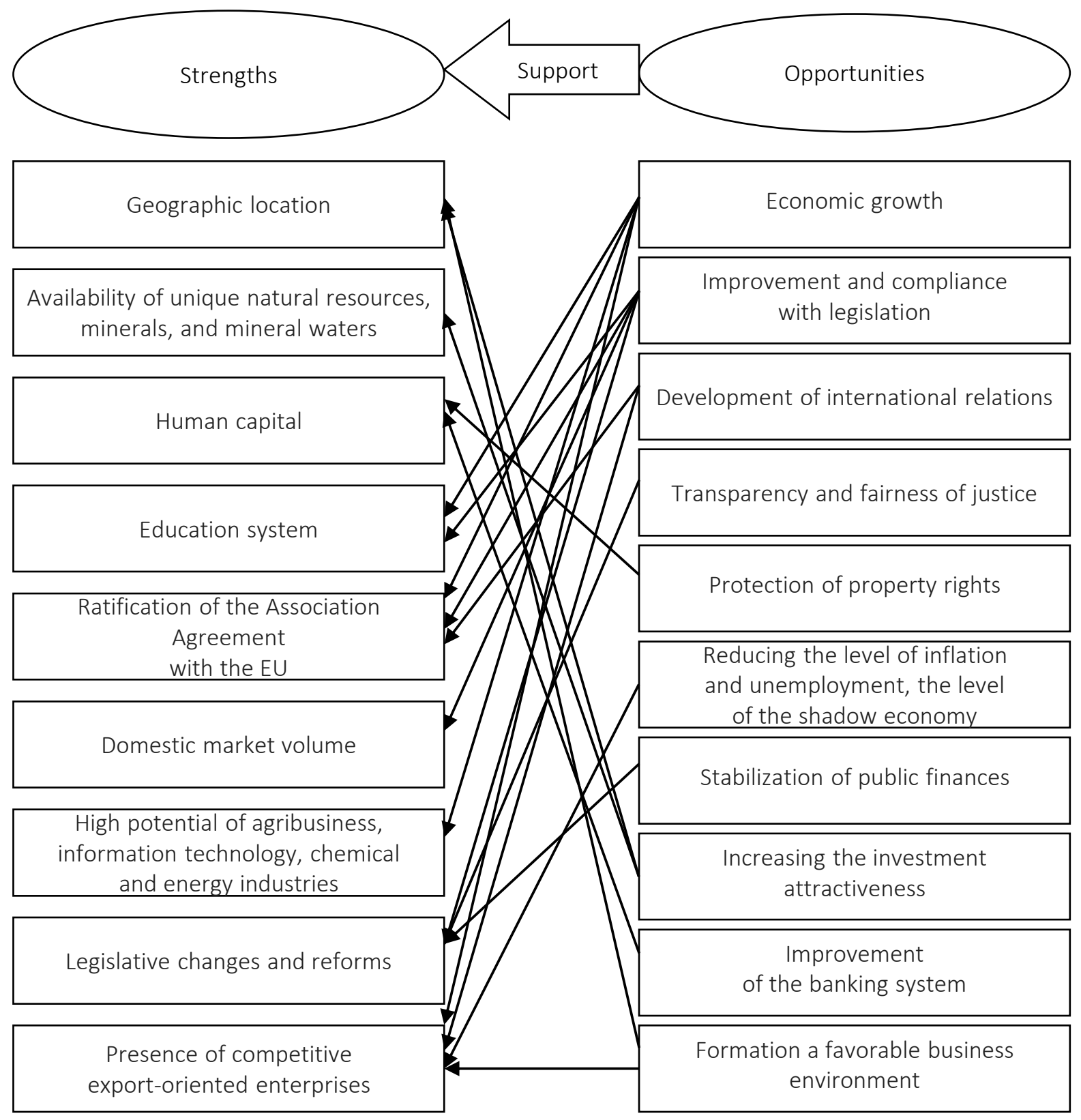

Figure 4. The relationship between the strengths and opportunities to improve the country's investment climate

The authors identified the positive and negative indicators of the investment climate (see Figure 7).

Positive factors of the investment climate include favorable geographical position of the country, available resources, developed economic potential. Among these factors - the country's entry into the leading integration associations of the states, significant size of its territory, sufficient population, stable political environment, no conflicts, permanent government changes, early elections, normalized legal environment, stability and impartiality of the law, investor's protection, the existence of an advanced system of state support and guarantees, the efficiency of the judicial system.

These are the socio-economic stability, modern domestic market, absence of double taxation, stable and transparent tax system, moderate tax pressure, strong banking system, convertible money, affordable credit, and low inflation, no restrictions 

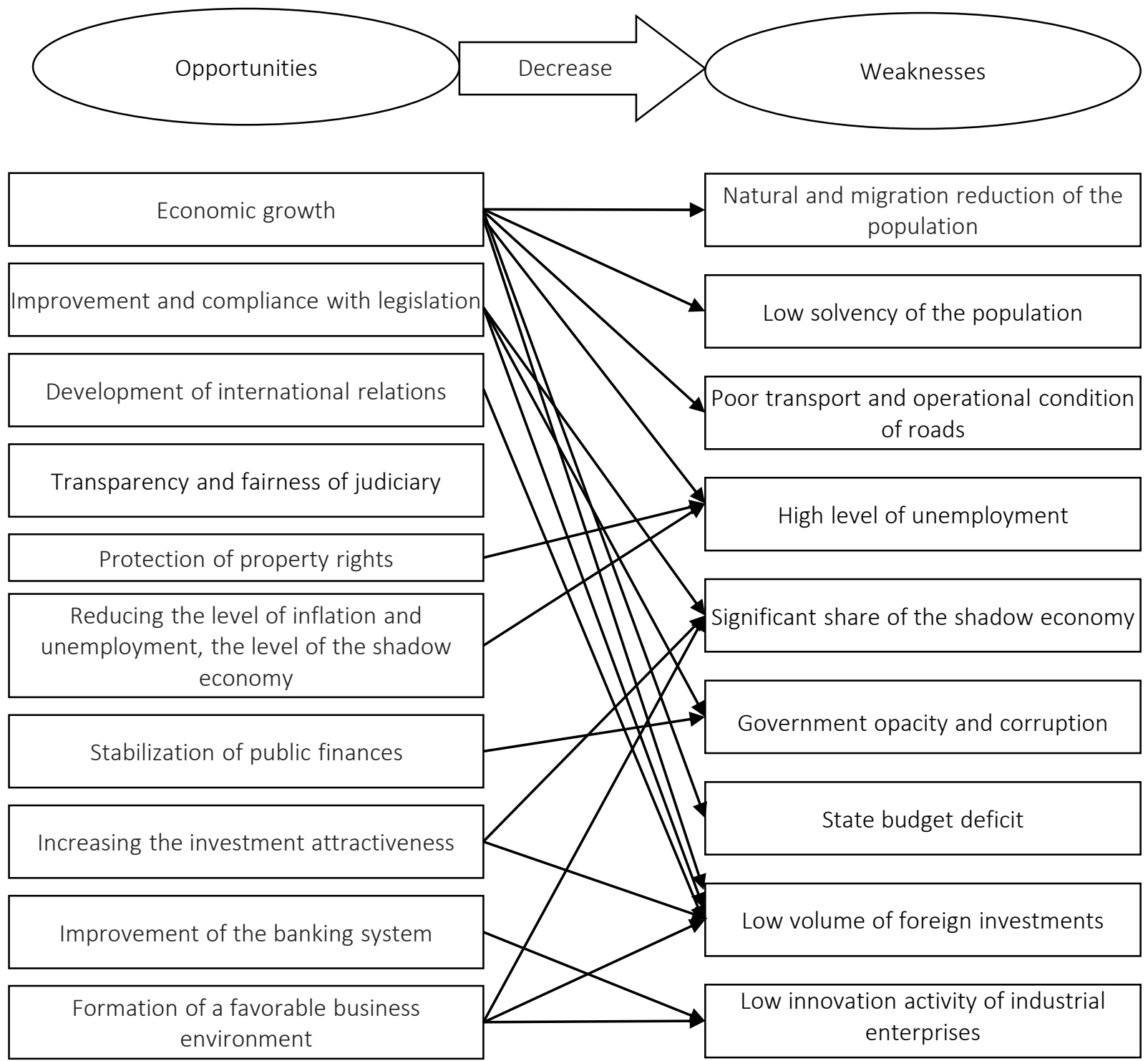

Figure 5. The relationship between the opportunities and weaknesses that affect the country's investment climate

on capital input and output, low customs. These are competitive advantages, low, predicted and controlled risk and their insurance (Tretiak, 2013).

An important factor in a favorable investment climate is the nature of regulatory impact, registration requirements for investors, the state of licensing, certification, standardization, control by public authorities, corruption, bribery, shadow and lobbying decision-making mechanisms, the degree of national legislation harmonization. These are the procedures, time, and number of documents for connection to the electricity grids, obtaining permits for construction, land, launch- ing and liquidation of the enterprise, overcoming the insolvency. Special for Ukraine are the implementation of the EU technical regulation standards, NATO standards. The most painful issues in Ukraine are the issues of the licensing system, the quality of the state control system, the hopelessly outdated technical regulation, the restrictions existence on the introduction/withdrawal of capital, profits, dividends, currency, as well as the lack of real state support and guarantees of investors.

Unfavorable investment climate in Ukraine is caused by instability, threats, and risks of hybrid war, inflation, imperfect legislation, changing tax system, high 


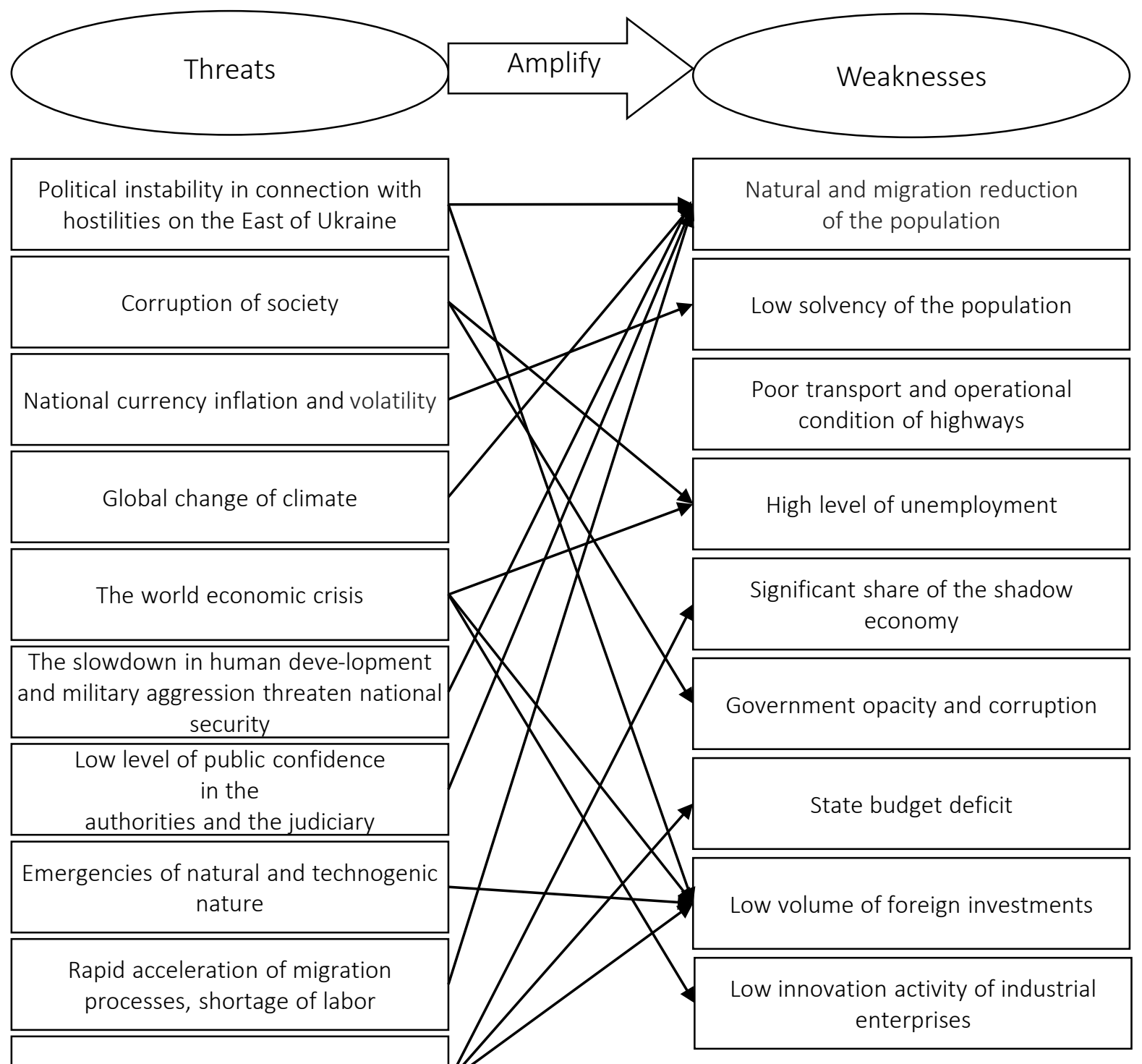

High level of shadowing of economies

Figure 6. The relationship between the threats and weaknesses that affect the country's investment climate

tariffs, cost of resources, risks of loss or depreciation been introduced in the country, leaving virtualof capital, bureaucracy, corruption, shady relations, ly no scope for reliable and efficient placement of low relations, and high poverty rate relations.

In Ukraine, there is no mechanism for the property rights protection, which is the basis for widespread raiding. Investment instruments have not pension funds, other institutional and direct investors. Such an instrument can function only by government securities. In the state, there is an ineffective, corrupt, inactive judicial system, in which no issue can be solved without money.

\section{CONCLUSION}

On the whole, the low level of Ukraine's investment attractiveness determines the need to implement the new strategy of the country's development, to define the tasks to be solved in the medium and long term. 


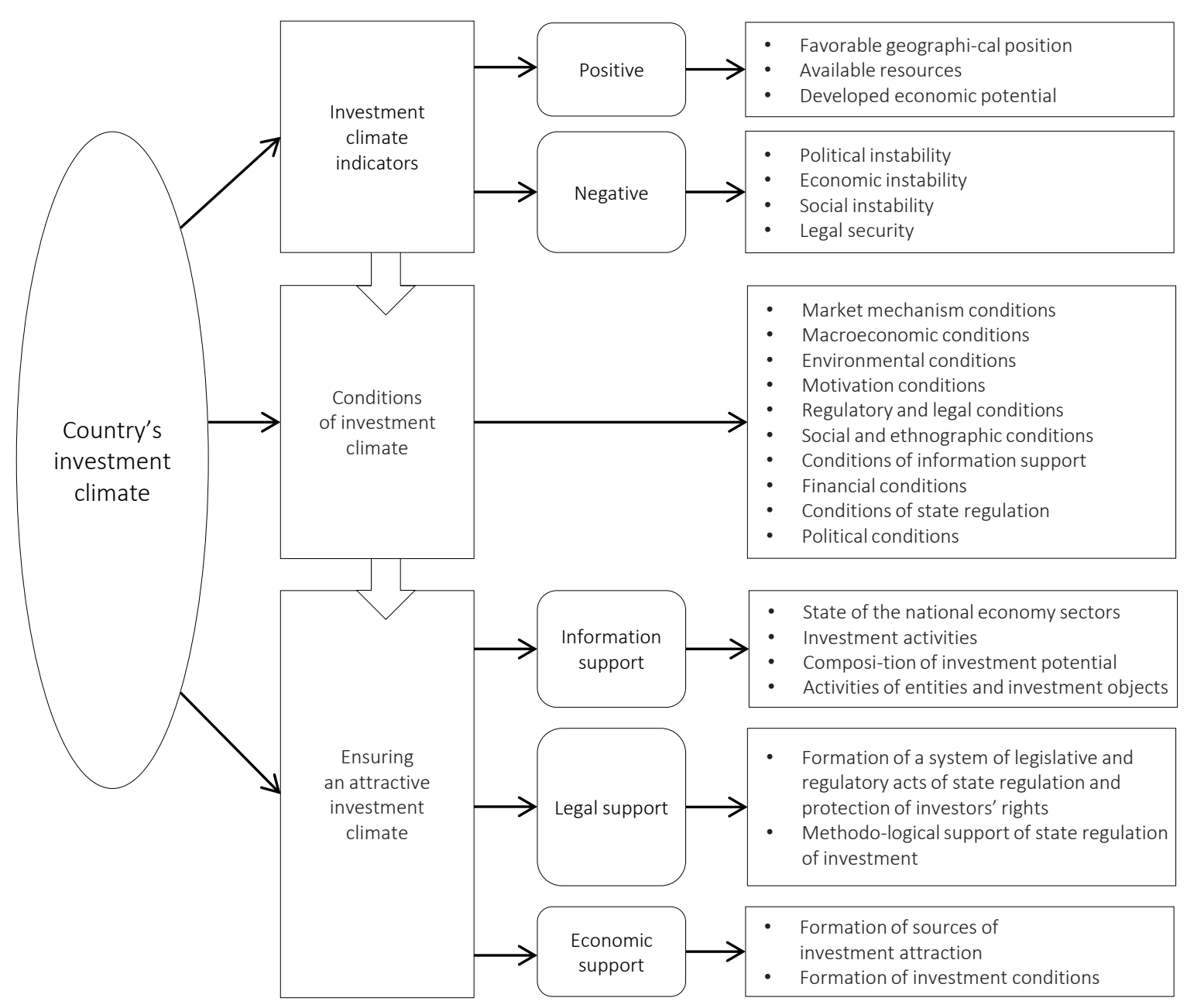

Figure 7. System of indicators of the country's investment climate formation and management

Objectively, it is necessary to develop the "Program of the economy development in Ukraine and restoration of people living standard" until 2025. It should ensure a significant increase in economic growth to $7 \%$ per year, increase the country's GDP by 2-2.5 times, and achieve pre-crisis level of people's real incomes.

Capital investment priorities and urgent and promising investment projects need to be identified. Some legislative and regulatory acts have been adopted on this issue. The priorities included agro-industrial complex, housing and communal complex, machine-building complex, transport infrastructure, resort and recreation sphere and tourism, as well as processing for industry. In 2016, National Investment Council was formed under the Head of State, which also identifies investment priorities in Ukraine.

The issue needs to be rethought in the context of the new demands of time, the need for deep structural restructuring of the economy, the realization of the tasks caused by the IV Industrial Revolution, the problems of strengthening the national security. The investment priorities include a significant increase in the share and volume of the modern mechanical engineering production, achievement of energy independence, introduction of energy-saving technologies, environmental protection, housing, health care, higher education, science, space, renewal and development of the military-industrial complex.

The introduction of digital and electronic technologies and the digital economy is urgent. In the most general form, the digital economy is understood as the technology of production, sales, supply of goods and services through computer networks and systems. 
It should be noted that the Digital Agenda for Europe is being actively implemented. The European Commissioner for Digital Economy and Society is functioning effectively in the EU.

It is necessary to create the conditions for implementation the investment projects. Public investment projects, which have been realized for only $45-48 \%$ during 2-3 years, do not have prospects without dramatic increase of funds for these purposes and introduction of medium-term budgetary planning.

The important areas for improving the investment climate in Ukraine are increasing the international reserves, strengthening the national money, increasing the exports, and converting the money. Exports of goods and services of Ukraine in 2012 amounted to USD 82.3 billion. In 2015, it dropped to USD 38.1 billion, though, as of 2018, has grown to USD 58.4 billion. Geopolitical, macroeconomic, and military threats and investment risks to Ukraine should be minimized (American Chamber of Commerce in Ukraine, 2019).

According to the analytical part of the study, the main problems that hinder the recognition of Ukraine as an attractive investment country include significant tax burden since the income tax rate in Ukraine $(18 \%)$ and the VAT rate $(20 \%)$ are higher than in many countries of Central and Eastern Europe; corruption at all levels of government, lack of transparent decision-making procedures by executive authorities; inability of mechanisms to ensure market rights and freedoms of investors, as well as low level of investor protection; hostilities in the East of Ukraine, as there is a large capital outflow through the occupied territories; there is also a high risk for the investor, in particular foreign investors face uncertainty as to how well their investments in Ukraine are protected in times of armed conflict and military occupation; lack of land reform; lack of confidence in the judiciary.

In the authors' opinion, the following measures should be taken into account in order to solve these problems and to improve the attractiveness of Ukrainian investment climate:

- reducing the tax burden and ensuring the stability of the political environment;

- fighting and eradicating the corruption at all levels of government, as well as ensuring the transparency of decision-making procedures by central and local executive bodies;

- fighting the inflation, smoothing out the cyclical fluctuations in the economy, reducing the unemployment;

- ensuring the effective functioning of the legal sphere, improving the legislation;

- updating the judicial system, the need to restore confidence in the courts, the authority of the court and judges should not be questioned;

- introducing of the economic mechanism of foreign investment risks insurance.

The complex of economic, social, and other problems in Ukraine will not be solved at the expense of external assistance. Within the framework of the National Investment Plan, in order to create an attractive investment climate, it is necessary to introduce a system of preferential taxation of foreign direct investment and direct national investment in priority sector development projects. Confidentiality regimes should be introduced through the investor activity, as is the case in Switzerland. With the participation of the state, it is necessary to create the institutions for support and assistance in the implementation of priority investment projects. This is just one aspect of a fundamental improvement in the investment climate in Ukraine. These issues are vitally important for the country and require further research, development, and managerial decisions. 


\section{AUTHOR CONTRIBUTIONS}

Conceptualization: Liudmyla Gavatiuk, Eduard Yurii.

Data curation: Alina Korbutiak.

Formal analysis: Liudmyla Gavatiuk, Alina Korbutiak, Natalia Sokrovolska, Maksym Karvatskyi, Eduard Yurii.

Funding acquisition: Liudmyla Gavatiuk, Alina Korbutiak, Natalia Sokrovolska, Maksym Karvatskyi, Eduard Yurii.

Investigation: Liudmyla Gavatiuk, Natalia Sokrovolska, Maksym Karvatskyi, Eduard Yurii.

Methodology: Liudmyla Gavatiuk, Alina Korbutiak, Maksym Karvatskyi.

Project administration: Liudmyla Gavatiuk, Eduard Yurii.

Resources: Alina Korbutiak, Natalia Sokrovolska.

Supervision: Liudmyla Gavatiuk, Natalia Sokrovolska, Maksym Karvatskyi.

Validation: Liudmyla Gavatiuk, Alina Korbutiak, Eduard Yurii.

Visualization: Liudmyla Gavatiuk, Alina Korbutiak, Natalia Sokrovolska, Eduard Yurii.

Writing - original draft: Liudmyla Gavatiuk, Alina Korbutiak, Natalia Sokrovolska, Maksym Karvatskyi, Eduard Yurii.

Writing - review \& editing: Liudmyla Gavatiuk, Alina Korbutiak, Natalia Sokrovolska, Maksym Karvatskyi, Eduard Yurii.

\section{REFERENCES}

1. Agénor, P.-R. (2009). Infrastructure Investment and Maintenance Expenditure: Optimal Allocation Rules in a Growing Economy. Journal of Public Economic Theory, 11(2), 233-250. https://doi.org/10.1111/j.14679779.2009.01408.x

2. Alexander, L., \& Eberley, J. (2018). Investment Hollowing Out. IMF Economic Review, 66(1), 5-30. https://doi.org/10.1057/s41308017-0044-2

3. American Chamber of Commerce in Ukraine (ACC). (2019). Ukraine Country Profile. http:// publications.chamber.ua/2019/ Ukraine\%27s_Economic_Outlook/Country_Profile_2019 EN.pdf

4. Aschauer, D. (1989). Public investment and productivity growth in the Group of Seven. Economic Perspectives, 13(5), 17-25. Retrieved from https://fraser.stlouisfed. org/title/5288/item/552469/ toc/521896

5. BDO. (2019). BDO International Business Compass 2019. Retrieved from https://www.bdo.com/ insights/industries/real-estate/ \%E2\%80\%8Bbdo\%E2\%80\%99s- 2019-real-estate-and-

construction-compass

6. Blakyta, G., Guliaieva, N., Vavdijchyk, I., Matusova, O., \& Kasianova, A. (2018). Evaluation of investment environment security in Ukraine. Investment Management and Financial Innovations, 4, 320-331. http://dx.doi. org/10.21511/imfi.15(4).2018.26

7. Bolton, P., Wang, N., \& Yang, J. (2017). Liquidity and Risk Management: Coordinating Investment and Compensation Policies (Meeting Papers No. 1703). Columbia University. Retrieved from https://ideas.repec.org/p/red/ sed016/1703.html

8. Cash, T. F., Melnyk, S. E., \& Hrabosky, J. I. (2004). The assessment of body image investment: An extensive revision of the appearance schemas inventory. International Journal of Eating Disorders, 35(3), 305-316. https:// doi.org/10.1002/eat.10264

9. Economic Discussion Club (2018). Pozytsiia Ukrainy v reitynhu krain svitu za indeksom hlobalnoi konkurentospromozhnosti 2017-2018 [Ukraine's position in the Global Competitiveness
Index 2017-2018]. (In Ukrainian). Retrieved from http://edclub.com. ua/analityka/pozyciya-ukrayinyv-reytyngu-krayin-svitu-zaindeksom-globalnoyi-konkurentospromozhnosti-2

10. Foreign Direct Investment in Ukraine (2019). Official website of the Ministry of Finance of Ukraine. Retrieved from https:// index.minfin.com.ua/ua/economy/fdi/

11. Gitman, L. J., \& Jonck, M. D. (2012). Fundamentals of Investment (10th ed.). NY: McGrawHill Education. Retrieved from https://www.amazon.com/ Fundamentals-Investment-Management-McGraw-Hill-insurance/ $\mathrm{dp} / 0078034620$

12. Grytsaienko, G. (2017). Investytsiina pryvablyvist Ukrainy [Investment attractiveness of Ukraine]. Agricultural and Resource Economics, 3(1), 80-93. (In Ukrainian). Retrieved from http://nbuv.gov.ua/ UJRN/areis_2017_3_1_9

13. Gusarova, M. Yu. (2017). Impact of "hard" and "soft" factors of competitiveness on the investment attractiveness of the regions of the country. Economic Bulletin 
of Zaporizhzhia State Engineering Academy, 1(2), 49-52.

14. Gutiérrez, G., \& Philippon, T. (2017). Investment-less Growth: An Empirical Investigation. Brookings Papers on Economic Activity (NBER Working Paper No. 22897). https://doi.org/10.3386/w22897

15. Ip, K., \& Jarry, J. L. (2008). Investment in body image for self-definition results in greater vulnerability to the thin media than does investment in appearance management. Body Image, 5(1), 59-69. https://doi.org/10.1016/j. bodyim.2007.08.002

16. Ishchuk, Y. (2018). Statistical monitoring of sustainable development National Statistics System in Ukraine: Current State, Problems, Prospects. Materials XIV International. Research Practice Conference on the occasion of Statistics Day (pp. 99-105). Retrieved from https://ir.kneu.edu.ua/bitstream/ handle/2018/30612/ichsur_16. pdf? sequence $=1$ \&isAllowed $=\mathrm{y}$.

17. Kharlamova, G. (2014). Investment security of Industries: rating assessment (case of Ukraine). Procedia Economics and Finance, 16, 657-668. https://doi.org/10.1016/ S2212-5671(14)00854-5

18. Legislation of Ukraine. (1996). Law of Ukraine "On the regime of foreign investment" No. 94/96-VR with amendments and additions. Retrieved from https://zakon4. rada.gov.ua/laws/show/93/96\%D0\%B2\%D1\%80

19. Legislation of Ukraine. (2016). Regulations on the National Investment Council (Decree No. 365/2016). Retrieved from https://zakon.rada.gov.ua/laws/ show/365/2016

20. Liga Biznes. (2018). Doing Business-2019: Ukraina podnyalas na 5 pozitsiy [Doing Business-2019: Ukraine has risen to 5 positions]. (In Russian). Retrieved from https://biz.liga.net/ekonomika/ all/novosti/doing-business2019-ukraina-podnyalas-na5-pozitsiy

21. Long, C., Yang, J., \& Zhang, J. (2015). Institutional Impact of Foreign Direct Investment in
China. World Development, 66, 31-48. https://doi.org/10.1016/j. worlddev.2014.08.001

22. Major, K., \& Szilagyi, K. (2009). Government investment in a small open economy. Acta Oeconomica, 59(2), 119-145. https://doi. org/10.1556/AOecon.59.2009.2.1

23. Maslak, O., \& Talover, V. (2016). Kompleksna otsinka investytsiinoi pryvablyvosti krainy [Complex assessment of country's attractiveness]. Ekonomichnyi forum

- Economic Forum, 3, 51-59. (In Ukrainian). Retrieved from http:// www.irbis-nbuv.gov.ua/cgi-bin/ irbis_nbuv/cgiirbis_64.exe?C21 $\mathrm{COM}=2 \& \mathrm{I} 21 \mathrm{DBN}=\mathrm{UJRN} \& \mathrm{P} 2$ $1 \mathrm{DBN}=$ UJRN\&IMAGE_FILE_ DOWNLOAD $=1 \&$ Image_file_ name=PDF/ecfor_2016_3_9.pdf

24. Ministry of Finance of Ukraine. (n.d.). Official website. Retrieved from https://mof.gov.ua/en

25. Ministry of Foreign Affairs of Ukraine. (2019). Investment climate of Ukraine. Retrieved from https://mfa.gov.ua/en/aboutukraine/economic-cooperation/ investment-climate-ukraine

26. Naveen, Kh., \& Richmond, D. M. (2011). Can herding improve investment decisions? RAND Journal of Economics, 42(1), 150-174. Retrieved from https://econpapers. repec.org/article/blarandje/v_3a42_3ay_3a2011_3ai_3a1_3ap_ 3a150-174.htm.

27. Ozymchuk, O. (2018). Vplyv investytsii na ekonomichnyi rozvytok Ukrainy [Impact of Investment on Economic Development of Ukraine]. Hlobalni ta natsionalni problemy ekonomiky - Global and National Problems of Economy, 6, 224-227. (In Ukrainian). Retrieved from http://global-national. in.ua/archive/6-2015/45.pdf

28. Palyvoda, K. (2013). Plan Marshalla yak pryklad dlia ukrainskoi ekonomiky [The Marshall Plan as an Example for the Ukrainian Economy]. Dzerkalo tyzhnia Mirror of the Week. (In Ukrainian). Retrieved from https://dt.ua/business/plan-marshalla-yak-prikladdlya-ukrayinskoyi-ekonomiki. html
29. Paranchuk, S., \& Korbutyak, A. (2013). Problems investment support innovative development of the national economy and solutions. Econtechmod. An International Quarterly Journal, 2(4), 5360. Retrieved from http://yadda. icm.edu.pl/baztech/element/bwmeta1.element.baztech-82808bec78a1-41ac-8313-f6552b361c15/c/ Paranchuk.pdf

30. Rognlie, M., Shleifer, A., \& Simsek, A. (2018). Investment Hangover and the Great Recession. American Economic Journal: Macroeconomics, 10(2), 113-153. https://doi. org/10.1257/mac.20160211

31. Rzaev, G., \& Vakulova, V. (2016). Metody otsinky investytsiinoi pryvablyvosti na rivni krainy ta perspektyvy yikh vykorystannia v ekonomichnomu analizi [Methods of assessing investment attractiveness at country level and prospects for their use in economic analysis]. Visnyk Khmelnytskoho natsionalnoho universytetu - Bulletin of Khmelnytsky National University, 3(1), 137-143. (In Ukrainian). Retrieved from http://irbis-nbuv.gov. ua/cgi-bin/irbis_nbuv/cgiirbis_64. exe?C21COM=2\&I21DBN=UJ RN\&P21DBN=UJRN\&IMAGE_ FILE_DOWNLOAD=1\&Image_ file $\_$name $=\mathrm{PDF} / \mathrm{Vchnu}$ ekon_2016_3(1)_29.pdf

32. Sineviciene, L., \& Vasiliauskaite, A. (2011). Fiscal policy interactions with private investment. Engineering Economics, 23(3), 233-241. https://doi.org/10.5755/ j01.ee.23.3.1934

33. State Statistics Service of Ukraine. (2019). Capital investment in Ukraine. Retrieved from https:// ukrstat.org/uk/operativ/operativ2018/ibd/kin/arh_kin_r_u.htm

34. State Statistics Service of Ukraine. (n.d.). Official website. Retrieved from http://www.ukrstat.gov.ua

35. Tretiak, N. (2013). Factors that form investment climate in Ukraine. Financial space, 3, 165170. Retrieved from http://oaji. net/articles/2014/944-1406538289. pdf

36. Vertiakova, Yu., \& Plotnikov, V. (2017). Problems of sustainable 
development worldwide and public policies for green economy. Economic Annals-XXI, 166(78), 4-10. Retrieved from https:// www.ceeol.com/search/articledetail?id=590979

37. World Intellectual Property Organization (WIPO). (2019). Global Innovation Index 2019: India Makes Major Gains as Switzerland Sweden, U.S., Netherlands, U.K. Top Ranking; Trade Protectionism Poses Risks for Future Innovation (Press Releases PR/2019/834). Retrieved from https://www.wipo. int/pressroom/en/articles/2019/ article_0008.html

38. Yamarik, S. (2011). State Level Capital and Investment: Updates and Implications. Contemporary Economic Policy, 31(1), 62-72. https://doi.org/10.1111/j.14657287.2011.00282.x

39. Yesscombe, E. (2015). Principles of Project Finance (408 p.). Moscow: Alpina Pablisher.

40. Yevropeiska Pravda [European Truth]. (2017). Indeks investytsiinoi pryvablyvosti Ukrainy vpav vpershe za kilka rokiv [Ukraine's investment attractiveness index fell for the first time for several years]. (In Ukrainian). Retrieved from https:// www.eurointegration.com.ua/ news/2017/12/19/7075256/

41. Yu, F., Guo, Y., Le-Nguyen, K., Barnes, S. J., \& Zhang, W. (2016). The impact of government subsidies and enterprises' R\&D investment: A panel data study from renewable energy in China. Energy Policy, 89, 106113. https://doi.org/10.1016/j. enpol.2015.11.009 